\title{
La (re)construcció visual i retòrica de Jaume I a la Festa de l'Estendard de Mallorca durant l'època foral
}

\section{The visual and rhetorical reconstruction of James I in the Festa de l'Estendard in Mallorca (13th-17th centuries)}

Francesc Granell SaLES francescgrsa@gmail.com

Universitat de València

Resum: L'article pretén adverar de quina manera es configurava i s’identificava la figura del rei en Jaume a la Festa de l'Estendard, la commemoració anual de la conquesta cristiana de la ciutat de Mallorca, mitjançant l'anàlisi dels elements visuals i retòrics planificats per al desenvolupament d'aquella. Cal parar atenció, concretament, a dos d'aquests elements: el portaestandard que anava a cavall ben abillat amb armadura i altres objectes i l'eloqüent prèdica-coneguda com el Sermó de la Conquesta- que pronunciava un clergue acreditat per a tal funció.

Paraules clau: Jaume I, imatge règia, festes de la Baixa Edat Mitjana, iconografia del poder, Regne de Mallorca

\begin{abstract}
This paper attempts to discuss the manner in which the image of king James I was customized and established in the Festa de l'Estendard, the annual commemoration ceremony of the christian conquest of the city of Mallorca. We will do so through an analysis of the visual and rhetorical elements planned for the unfolding of the ritual. One should focus particular attention on two of these elements: the standard bearer on horseback well attired in armour and other objects and the speech known as the «Sermó de la Conquesta» delivered by a cleric.
\end{abstract}

Keywords: James I of Aragon, Royal Image, Late Medieval Ceremonies, Iconography of Power, Kingdom of Mallorca 
Francesc Granell Sales. La (re)construcció visual i retòrica de Jaume I a la Festa de l'Estendard de Mallorca durant l'època foral

\section{Introducció}

Fou el 31 de desembre de l'any 1229 quan les tropes catalanoaragoneses sota el comandament del rei en Jaume el Conqueridor vencien la resistència dels almohades i entraven a la medina Mayurqa per bab al-kofol, una de les portes de la muralla musulmana. A diferència de la presa de la ciutat de València, allí es va produir una batalla ferotge, sagnant, on els soldats cristians van ser autoritzats al pillatge i la matança pel rei mateix. Tres anys després tota l'illa restava sota el domini cristià. L'annexió de Mallorca als territoris confederats era la primera gesta que aconseguia Jaume I, un rei que havia heretat una corona amb poques perspectives d'èxit, després que son pare perdera la vida a la batalla de Muret (1213). L'illa representava un enclavament geogràfic clau de la mar Mediterrània i la Corona d'Aragó, en aquells moments, començava a esbossar-se com un imperi amb pretensions d'expansió cap a les regions de l'est, objectiu que es perfilarà amb posterioritat a la colonització del regne de València.

La Festa de l'Estendard ${ }^{1}$ commemora anualment aquella victòria que es produí a la porta de bab al-kofol-batejada posteriorment com la Porta Pintada o la Porta de Santa Margalida-, accés per on es cregué que va passar l'estendard, l'emblema dels reis de la casa d'Aragó consistent en quatre pals de gules sobre camper d'or. Les primeres referències sobre la Festa de l'Estendard daten del primer quart del segle XIV, si bé les al lusions del cronista Ramon Muntaner (1265-1336), qui fou ciutadà de Mallorca l'any 1287, fan pensar que la commemoració del 31 de desembre es realitzaria des de temps del rei en Jaume.

Per tant, el rang temporal que abasta el present estudi és ampli -al voltant de quatre centúries-, des dels temps del Conqueridor fins a l'època anterior a la Guerra de Successió, conflicte del qual isqué victoriós Felip V, qui manà aprovar el Decret de Nova Planta (1715). En aquell, Felip V, primer Borbó de la línia dinàstica hispànica, va modificar la naturalesa de les institucions executives mallorquines, principals organitzadores de la Festa de l'Estendard. Però dins d'aquesta àmplia cronologia determinada, l'article pretén adverar un element concret de la cerimònia festiva: la representació del rei en Jaume mitjançant la imatge i la paraula. És aquesta una acció recordatòria, es torna a presentar a un monarca ja mort; tanmateix, dita recordació suposava fer memòria d'un monarca particular atès que era, ni més ni menys, que el pater patriae ${ }^{2}$.

1 El cerimonial de la festa ha estat estudiat per qui fou arxiver i cronista de Palma, Benito Pons i Fàbregues (1907), pel pare Llompart (1974; 1977; i 1980), pel filòleg Antoni Ignasi Alomar (1998) i per l'historiador Antoni Quintana (1998).

2 Certament, no abunden els especialistes que han elaborat publicacions sobre la imatge de Jaume I. Els que se n’han dedicat, però, ho han fet d'una manera solvent. El professor Serra Desfilis (2007) ha tractat la configuració artística del mite de Jaume I en el context de la Corona d'Aragó i de l'estudi de la iconografia del Conqueridor se n'ha ocupat Serrano (2008; 2011a; 2011b; 2015). 
Francesc Granell Sales. La (re)construcció visual i retòrica de Jaume I a la Festa de l'Estendard de Mallorca durant l'època foral

\section{Breus apunts sobre el cerimonial de la Festa de l'Estendard}

La Festa de l'Estendard és una commemoració col lectiva d'un esdeveniment històric que segueix celebrant-se en els nostres dies. Encara que dista de ser el que fou, l'herència d'antuvi ha romàs en certs aspectes, malgrat les vicissituds de la història que l'han feta derivar en una festa hereva de la decadència huitcentista. Evidentment, una atenció considerable es va dedicar i es dedica a l'estendard reial; nogensmenys, el cerimonial ha anat modificant-se al llarg dels temps, com també ho ha fet durant l'època foral. No és el propòsit d'aquest estudi elaborar una somera descripció de la festa i les seues variacions des del segle XIII fins al XVII -els especialistes en qüestió s'han ocupat d'açò-, però, no obstant això, sí que cal introduir-ho per configurar un context adequat on s'inserirà aquella reconstrucció retòrica i visual del rei en Jaume.

La documentació exhumada sobre el cerimonial de la Festa que abasta els segles susdits no permet establir els canvis exactes que anaren produint-se. A grans trets, però, es pot determinar un desenvolupament anàleg pel que fa a la seua programació com un espectacle cívic, on el patriciat urbà comença a «ritualitzar» les formes d'expressió política (Narbona 2003: 82-83). Un document de l'any 1358 expedit per la cancelleria de Pere el Cerimoniós i una consueta datada al tombant del segle XVI (Llompart 1974: 323-326) mostren dos moments recents de l'evolució de la Festa. Així mateix, la Festa de l'Estendard consistia en dues desfilades: una conformada per clergat secular i regular de la ciutat i l'altra conformada per una comitiva de genets i infants on hi anava el ver estendard, el vexillum regium. Ambdues partien de la seu, tot seguint itineraris concrets, fent les parades pertinents, i confluien extramurs. La processó sortia de la ciutat per la Porta de Sant Antoni i, prop d'aquesta, a un enclavament anomenat el Peiró, un frare -normalment dominic o franciscà- pronunciava el Sermó de la Conquesta, un discurs extens i eloqüent que bàsicament tractava sobre l'efemèride bel licosa dels exèrcits comandats pel Conqueridor. Després, acabat el Sermó, la desfilada continuava extramurs fins a la Porta de Santa Margalida o Porta Pintada, portada on succeïa el punt àlgid de la celebració, el fet d'hissar l'estendard per sobre de la dita portada mitjançant un sistema complex de cordes ideat per mariners contractats ad hoc [fig. 1]. Finalment, la processó tornava al lloc d'on havia partit, la Seu.

Malgrat la presència continuada del Sermó a l'època foral, aquest no sempre es pronuncià al Peiró, com més endavant es dilucidarà. Tampoc l'itinerari fou sempre el mateix ni, consegüentment, el fet d'enarborar l'estendard per sobre de la Porta Pintada ocorregué d'aquella manera. Aquesta descripció general del cerimonial correspondria més bé a la celebració tardomedieval de la Festa que, com ja ha assenyalat el pare Llompart (1980: 11), evidencia coincidències suficients respecte del ritual que es realitzava cada 15 de juliol a Jerusalem -després que els croats prengueren Terra Santa aquell dia de l'any 1099- com per a determinar aquest ritus com l'antecedent de la cerimònia de l'Estendard. Llavors, a Jerusalem també se celebrava l'aniversari de la presa de la ciutat als musulmans, la Primera Croada, mitjançant una processó que partia de l'Església del Sant Sepulcre fins l'enclavament de la muralla pel qual van entrar les hosts, on justament es feia un sermó sobre 
Francesc Granell Sales. La (re)construcció visual i retòrica de Jaume I a la Festa de l'Estendard de Mallorca durant l'època foral

l'esdeveniment (Pernoud 1977: 101). A més a més, la Conquesta de Mallorca fou proclamada, també, com una croada per la cancelleria pontifícia.

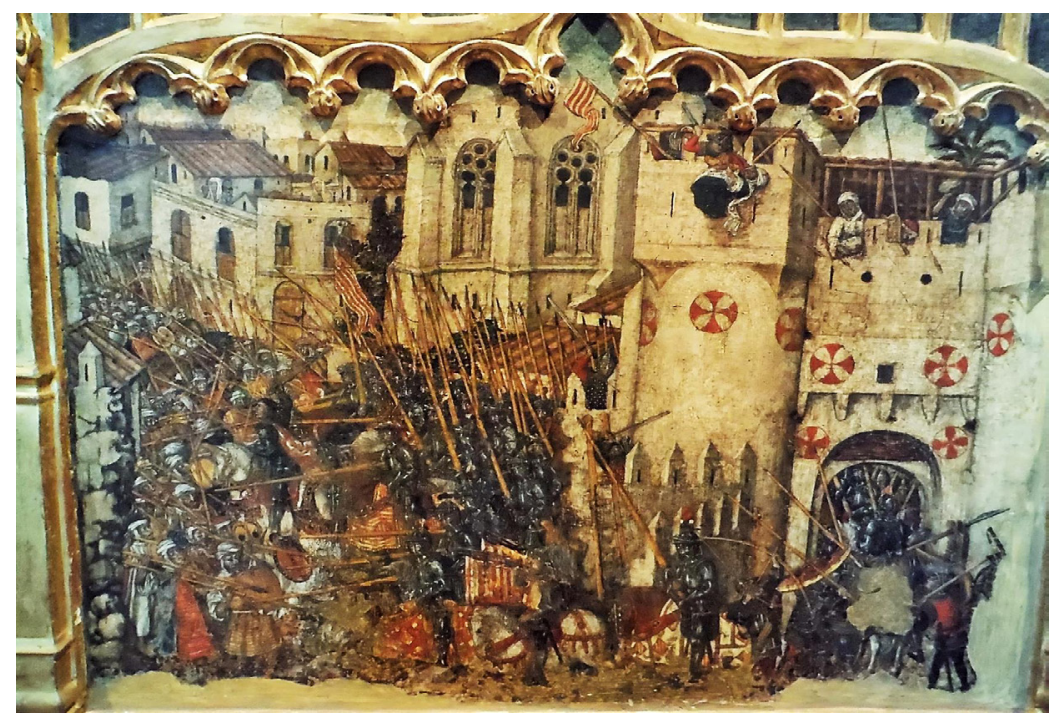

Fig. 1: L'estendard hissat a bab al-kofol, detall d'una taula de la predel la del retaule de sant Jordi, Pere Niçard i Rafel Mòger, 1468-1470, Museu Diocesà de Palma.

\subsection{La festa urbana i les elits municipal i eclesiàstica}

Certs fets concomitants permeten designar la Festa de l'Estendard durant l'època foral com una celebració que va restar força apropiada per part de les elits mallorquines que l'organitzaven. Nogensmenys, de bon principi no fou així. Fins al segon quart del segle XV el cerimonial festiu transcorria d'una manera no massa dissemblant al que just dalt hem apuntat. Aleshores, s'esdevindran uns canvis que evidenciaran una apropiació del discurs cerimonial de la Festa per part de les elits; i l'esmentada apropiació es va reafirmar al segle XVI, quan l'Espanya imperial protocol litzà la fastuositat de les festes i quan aquest estat territorial absolut dels primers Àustries hagué de defensar l'illa de Mallorca per ser un dels punts estratègics de la Mediterrània, juntament amb Malta i Sicília.

En qualsevol cas, durant el desenvolupament de la festa tardomedieval, no costa gaire imaginar les gents que es congregarien entorn a la desfilada, ni tampoc l'aglomeració de vassalls que assistirien a apreciar, any rere any, l'eloqüència del predicador del Sermó de la Conquesta. No s'ha de menystenir que era una festivitat anunciada amb antelació per joglars que viatjaven arreu dels pobles 
Francesc Granell Sales. La (re)construcció visual i retòrica de Jaume I a la Festa de l'Estendard de Mallorca durant l'època foral

circumdants de la ciutat. Costa menys imaginar, si escau, l'aplec popular. I és que la documentació (Calafat / Quintana 1992: 42) al ludeix específicament a aquesta multitud de gent aglomerada que, ajaguda, escoltava el discurs: «extra dictam civitatem gentium innumera multitudo ubi videlicet in planicie portales sancti Anthoniì (Cfr. Llompart 1977: 220). En canvi, els principals càrrecs municipals que regentaven el poder executiu, els jurats, no estaven d'ajaguts escoltant el Sermó, sinó asseguts a uns cadirats confeccionats exprofesso, als quals també degueren asseure's altres dignitats religioses (Font i Obrador 1964: 246).

Tothom sabia què anava a contar aquell predicador, atès que no debades es passejava la crònica reial redactada pel dominic mallorquí Pere Marsili, el Liber Domini Regis Illustrissimi Gestorum Iacobi, la qual relatava els fets del regnat del Conqueridor (Pons i Fàbregues 1907: 33). Aquesta era una adaptació llatina del Llibre dels Fets i es confeccionà justament per servir de base històrica al Sermó de la Conquesta. La seua exhibició pública l'abocava a la identificació, per part de l'auditori, i, en conseqüència, qualsevol oient podia tenir la consciència d'estar coneixent la veritat dels fets passats mentre escoltava la prèdica.

A la Festa també tingueren una presència constatada els artesans -ferrers, argenters, teixidors, sastres, entre altres-, ja que cada any desfilaven un o dos gremis armats, incorporats a la comitiva de genets $\mathrm{i}$ infants, tot constituint una guàrdia d'honor a peu. Així, amb tot plegat, a la festa baixmedieval es pot apreciar la presència dels estaments més i no tant baixos agrupats al costat dels grups dominants d'aquella societat, els quals tenien el paper preeminent de sistematització de la cerimònia.

Advingut l'Estat cesarista de l'emperador Carles V, els espectacles reials s'aristocratitzaren i els vassalls passaren d'exercir en qualitat de copartíceps de la festa a esdevenir mers espectadors passius (Massip 2010: 209-211). A tall de pròleg a aquest procés d'aristocratització del fet festiu, els jurats s'apropien de l'objecte central, l'estendard. A partir de la dècada dels cinquanta del segle XV desapareixen les notícies que versaven sobre el muntatge que elevava el penó de la conquesta a la Porta Pintada. Llavors, l'estendard va restar fixe a la plaça de Cort, la plaça on es trobava l'antiga Casa dels Jurats. Aquest era un fet que prestigiava la institució municipal, la qual pretenia enarborarse per gaudir d'un protagonisme manifest. L'estendard ja no s'hissaria més a la Porta Pintada; els jurats l'exposaven al balcó de la Casa sobre sis coixins i una tela de damàs vermell per reverenciar-lo la vespra de la Festa amb una banda de músics i el dia 31 de desembre el treien per col locar-lo a la plaça de Cort, lloc on la visió de l'estendard es complementava amb la del retrat del rei en Jaume -col locat a un balcó de la plaça sota un dosser- el qual saludaven en senyal de veneració (Quintana 1998: 156) [fig. 2] $]^{3}$.

3 El retrat actual, conservat a l'Ajuntament de Palma, és una còpia d'una taula gòtica que féu el pintor Andreu Reus, en conseqüència, manté els trets comuns dels retrats reials europeus del segle XIV amb el rostre de perfil i el cos en posició de tres quarts (Falomir 1996: 182). 


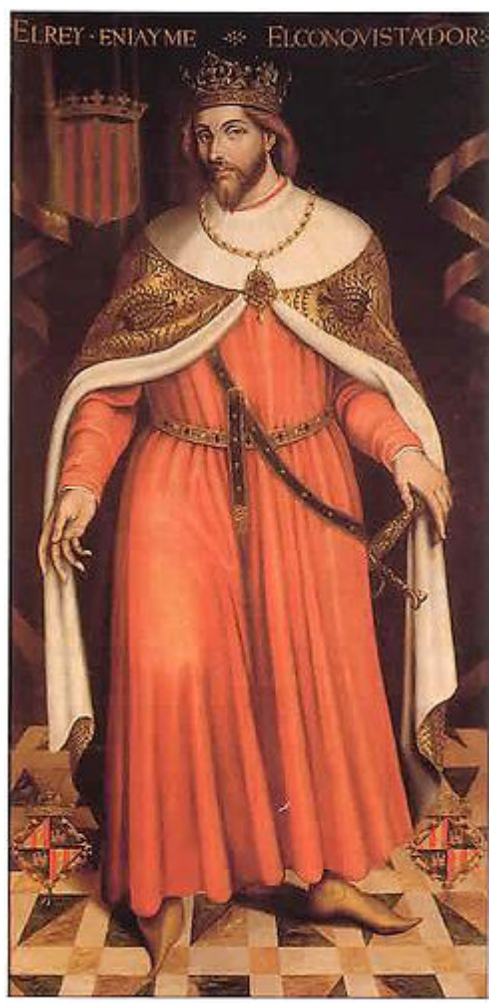

Fig. 2: Retrat del rei Jaume I, Andreu Reus, ca. 1623, Ajuntament de Palma.

Malgrat introduir-se a les acaballes del segle XV (Weyler 1968: 48), tot sembla indicar que a mitjan segle XVI s'estableix la Qualcada -una companyia de genets cavallers sovint capitanejats pel batlle o el veguer, que marxava abans de i durant el recorregut de la desfilada- amb unes intencions socials i polítiques a la Festa de l'Estendard. Sense extraure llur significat d'exhibició eqüestre, de desfilada triomfal que refermava el grau d'espectacle, la seua omnipresència -se li atorgà tanta importància que va canviar el nom de la Festa fins ben entrat el segle XIX-es deu a què representava la defensa militar de la ciutat. Una ciutat posterior a la sufocació dels agermanats, que seguia tement les possibles revoltes dels esclaus, així com dels moriscos (Quintana 1998: 137-138). I és que al llarg del segle XVI es produïren continus desembarcaments de sarraïns a les costes mallorquines, és per això que no debades es creà l'any 1551 un pla de defensa de l'illa; ni tampoc pareix casual la implantació del Tribunal de la Rota el 1571 a la ciutat de Mallorca, per ordre de Felip II. La Qualcada, doncs, coadjuvava a l'aristocratizació de la Festa, tot suposant una visualització del resguard respecte de les amenaces internes i externes de la ciutat.

A l'apropiació per part del patriciat urbà s'ha de sumar l'apropiació per part de l'altre grup organitzador i partícip de la Festa: el clergat. El ritual públic esdevé eminentment institucional i cavalleresc, i doncs, l'Església no volgué restar a banda. També fou a mitjan segle XVI quan el 
Francesc Granell Sales. La (re)construcció visual i retòrica de Jaume I a la Festa de l'Estendard de Mallorca durant l'època foral

Sermó de la Conquesta ja no es feia al Peiró, a una esplanada extramurs, atès que va començar a pronunciar-se a un àmbit que gaudia d’un aforament més limitat: la seu de Mallorca [fig. 3].

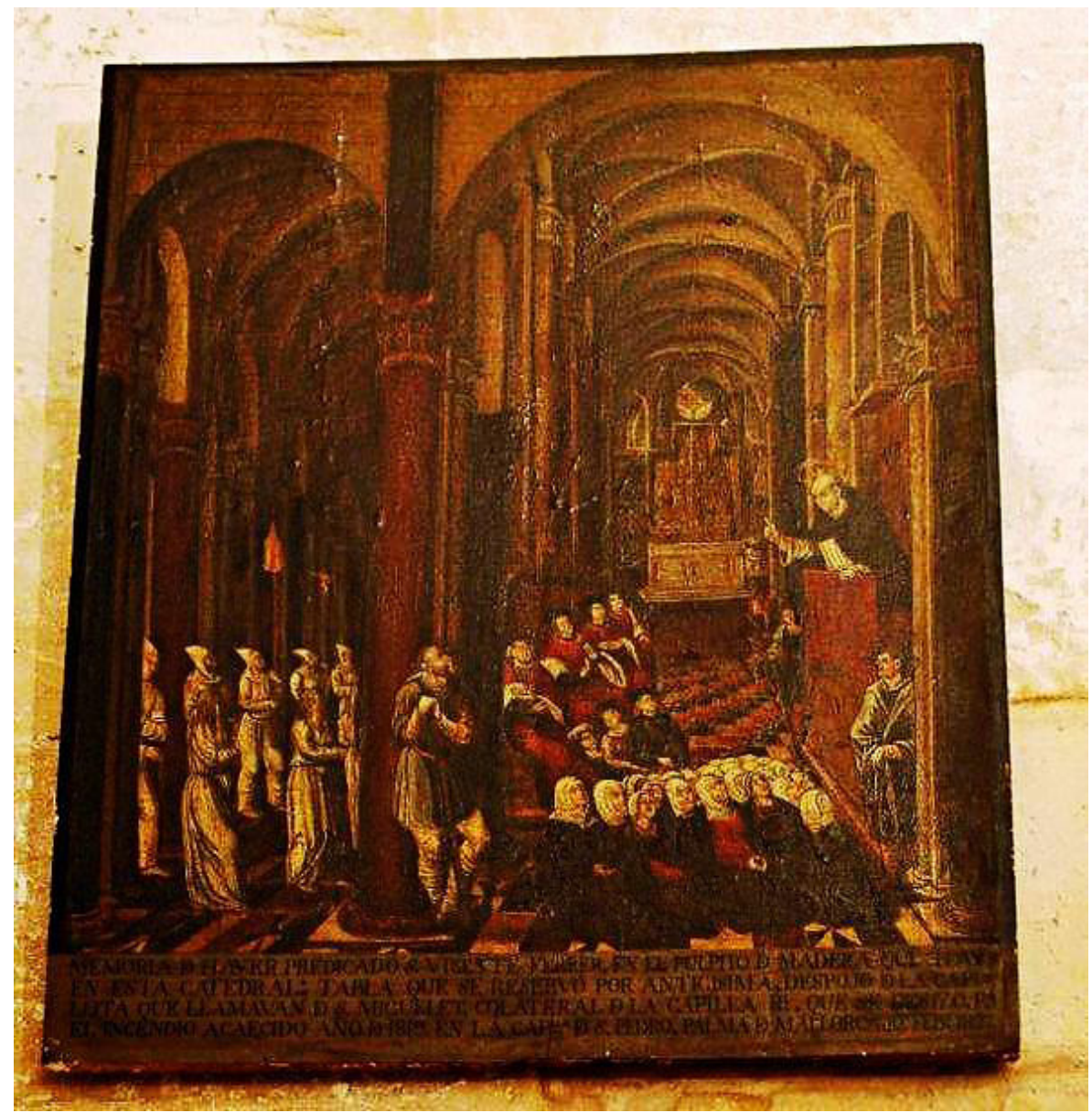

Fig. 3: Taula de la predicació de sant Vicent Ferrer, Bartomeu Martínez i

Bartomeu Pol, 1520, Museu Diocesà de Palma.

\section{La (re)construcció retòrica i visual del rei en Jaume: el Sermó i l'home abillat}

Com a primera gesta del rei, la conquesta de Mallorca ocupa un lloc preeminent al Llibre dels Fets, la crònica que el rei en Jaume mateix va dictar a la fi del seu regnat, vers l'any $1270 .{ }^{4}$ Aquesta fou la primera crònica règia que va funcionar com una mena d'evangeli laic, perquè el seu objectiu era afirmar una ideologia oficial de la cort i de la dinastia del Casal d'Aragó, tot produint èpica a

\footnotetext{
4 La idea subjacent a la redacció de la crònica i la cronologia suara esmentada està plantejada i raonada per Cingolani (2008). En aquest sentit, vegeu també els estudis d'Escartí (2012) i l'estudi introductori a l'edició del Llibre dels Fets elaborat per Escartí i Ferrando (2008).
}

SCRIPTA, Revista internacional de literatura i cultura medieval i moderna, núm. 9 / juny 2017 / pp. 194-207 ISSN: 2340 - 4841 doi:10.7203/SCRIPTA.9.10341 
Francesc Granell Sales. La (re)construcció visual i retòrica de Jaume I a la Festa de l'Estendard de Mallorca durant l'època foral

partir de la realitat (Sobré 1978: 121-122). El Llibre dels Fets és, doncs, un llibre de lloança, d'una propaganda total, on s'argumenta que Jaume I conquerí Mallorca perquè així ho va determinar la voluntat divina. No es pot ometre aquesta font escrita a l'hora d'analitzar la Festa de l'Estendard, ja que Jaume II el Just, nét de Jaume I, ordenà confeccionar una adaptació llatina del Llibre dels Fets al dominic Pere Marsili, la qual s'enllestí l'any 1314, i una còpia d'aquesta es va enviar un any abans a la biblioteca del monestir de predicadors de la ciutat de Mallorca per una causa concreta: perquè el predicador en qüestió l'usara com a base històrica del Sermó de la Conquesta (Biosca 2011: 55).

Dita prèdica durava hores $\mathrm{i}$ havia de recontar l'efemèride històrica d'una manera solemne. De fet, l'orador era escollit per la seua veu potent (Llompart 1977: 220-221). La font històrica per antonomàsia, com s'ha especificat, era el Liber Domini Regis Illustrissimi Gestorum Iacobi de Marsili, una còpia del qual -conservada actualment a l'Arxiu del Regne de Mallorca (Ms. 40)- conté una traducció catalana del segon llibre, el dedicat a l'episodi de la Conquesta. No obstant això, no era l'única font que servia de fonament històric, verbigràcia, també la Crònica de Bernat Desclot fou objecte d'estudi i, a partir del primer terç del segle XVII, els predicadors del Sermó degueren llegir les dues primeres històries del Regne de Mallorca que redactaren, respectivament, el cronista i metge Joan Binimelis (1601) i el jesuïta Joan Dameto (1633). Ací es menciona el rei en Jaume qualificant-lo de «incomparable príncipe», «invictísimo conquistador», qui aconseguí gestes dignes del «heroico pecho del grande Conquistador nuestro», car les seues gestes són tan solemnes que «Muda quedara aquí toda la elocuencia assí ática como romana» (Dameto 1632: 192).

Però més enllà de les fonts que permetrien dilucidar la naturalesa d'aquell discurs en un moment determinat, es pot acudir a l'únic sermó conservat de la Festa de l'Estendard durant l'època foral. Aquest és el que es va elaborar l'any 1644, el qual ha estat transcrit i editat per Calafat i Quintana (1992: 117-180). Com bé assenyalen els autors, el sermó no conté cap tipus de puntuació, cosa que subratlla el fet que el redactor, el predicador mateix, faria ús de les seues qualitats oratòries quan estiguera sobre la trona de la Seu. Una trona que, no s'ha d'oblidar, estava situada en un espai no massa allunyat del sepulcre de Jaume II, el primer sobirà de la monarquia privativa del regne de Mallorca, fill del rei Jaume el Conqueridor. Era, doncs, una disposició espacial que ratificaria el contingut d'un sermó lloador del pater patriae mitjançant un vincle «auditivovisual» destacadament monàrquic.

Si ens fixem ara en el Sermó de la Conquesta de l'any 1644, què en diu sobre la concepció del rei en Jaume? D'entrada, el personatge de Jaume I es proclama davant la col lectivitat amb una càrrega providencialista potent: ell és el «gran Creador» i ell és el Messies. Creador perquè els va atorgar la pàtria i Messies perquè acomplí la profecia de conquerir Mallorca. La seua persona està sent comparada contínuament amb la de Crist: les seues gestes van ser divines, així com les seues paraules i accions pietoses i reconfortants, com aquella que succeí a la mort dels Montcada, veritables màrtirs cristians, segons el relat: «si Cristo plorà per veure mort a son germà [Llàtzer] (...), quals havien de ser las llàgrimes del rei don Jaume» (Calafat / Quintana 1992: 154). També 
Francesc Granell Sales. La (re)construcció visual i retòrica de Jaume I a la Festa de l'Estendard de Mallorca durant l'època foral

mitjançant una comparació amb Nostre Senyor, el rei parla a l'armada mentre la travessia marítima cap a Mallorca es complicava, car s'aixecava una tempesta amenaçadora:

\begin{abstract}
Respongué lo que respongué Cristo a los deixebles quan embarcats passaren aquella fortuna (...): «Co, que tiniu poca fe la cause de Cristo anem a fer. Ell és el nostro sigur, ell és el nostro amparo. No temeu, covarts! Animau la fe y resistiu valerosos a estos colps rigorosos de fortuna» (Calafat / Quintana 1992: 141).
\end{abstract}

En veritat, Jaume I no fou un rei que destacara en qualitat de pietós, sobretot si hom el compara amb monarques coetanis al seu regnat. Realment el turmentava més el seu paper de creador que no el de criatura de Déu (Cingolani 2010: 13). Encara així, la posteritat el lloava com un monarca d'una religiositat fervent per haver conquerit tres regnes a l'islam, haver fundat innumerables esglésies i haver organitzat una croada a Terra Santa. Àdhuc fou considerat des del segle XIV com el «sant rei» pel rei Pere el Cerimoniós, un cronista com Ramon Muntaner i pels jurats del municipi de València, consideració que es mantingué ben vigent havent transcorregut tres centúries quan a l'any 1633 se l'intentà canonitzar, encara que infructuosament. Així mateix, és al Sermó en qüestió on arriba a atribuir-se la voluntat de conquerir Mallorca a l'esperit religiós del rei: «incendi amorós de propagar la llei de Cristo y fixar en nostres islas los standats de la fe crestiane». I malgrat que el rei no va participar en les batalles que propiciaren la invasió de la medina Mayurqa, el predicador el descriu com un autèntic guerrer: «Arremet el rey ab son exèrcit contra el del moro» (Calafat / Quintana 1992: 154).

D’aquesta manera es presentava un monarca mític al públic oient. Tanmateix, tot no restava únicament en l'aprehensió auditiva. Si es fa parlar als documents exhumats, pot discernir-se que els espectadors de la Festa de l'Estendard degueren veure la recreació de Jaume I el Conqueridor en la desfilada que precedia i/o succeïa al Sermó de la Conquesta. I és que hi havia un home a cavall que destacava pel seu abillament opulent: sobrevesta, armadura, sella, estreps, guants, elm, la cimera del drac alat i, fins a mitjan segle XV, l'estendard reial. Al costat del bisbe de Mallorca, aquest era l'únic personatge que sobresortia respecte del seguici a tota la desfilada. En efecte, ell era el portaestendard, el penoner, el qual, guarnit d'aquest armament, arribava a necessitar l'ajuda d'un sabater que l'auxiliara en cas de que la situació ho exigira -l'estendard, l'asta i el pom devien ser realment pesats. Però, malgrat carregar amb tant de pes, hi havia la voluntat perquè fóra una sola persona, recobert amb unes armes específiques, la que duguera l'estendard. A més, aquesta persona no podia ser qualsevol: Pere el Cerimoniós va determinar qui havia de portar-lo i la centúria següent es va estipular que el penoner havia de ser el jurat més jove (Llompart 1977: 220).

Així les coses, el públic assistent contemplava un personatge que fins el començament del segle XVII portava unes armes que l'individualitzaven, tot atorgant-li una categoria particular. La sella, els estreps i el petó de junyir -hui en dia conservats a la Reial Armeria de Madrid-podrien no ser objectes que ratificaven la visió d'un portador peculiar per si mateixos; no obstant això, cal destacar que es creien part d'un equipament que va portar el rei en Jaume (Quintana 1998: 117-118), i així, 
Francesc Granell Sales. La (re)construcció visual i retòrica de Jaume I a la Festa de l'Estendard de Mallorca durant l'època foral

en el moment en què deixaren de tenir una utilitat pràctica per a esdevenir peces expositives a la Festa de l'Estendard, es classificaren com a objectes del Conqueridor. Si bé no és una tasca fàcil acoblar una cronologia més o menys estreta a la sella i als estreps, el petó de junyir -una armadura protectora del pit típica dels cavallers de les justes- ha sigut datat pels especialistes a la segona meitat del segle XV (Alomar 1994: 73-74) i d'ençà que degué usar-se.

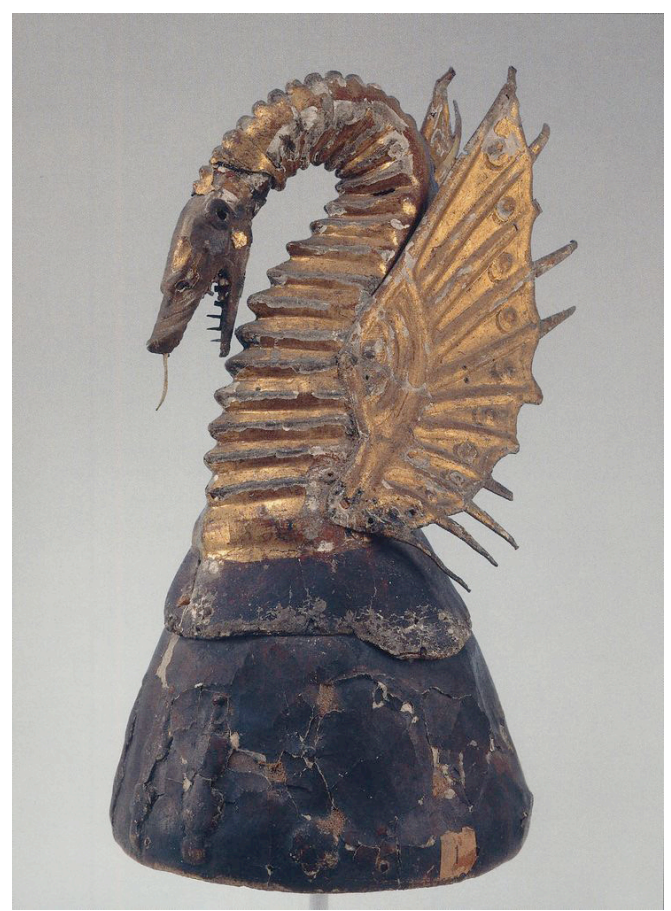

Fig. 4: Cimera del drac alat de Martí l'Humà, ca. 1407, Reial Armeria de Madrid.

També conservada a la Reial Armeria es troba la cimera del drac alat [fig. 4] que va dur aquell personatge, la qual sí que ratificava la visió d'un portador peculiar, car va ser un emblema reial que el Cerimoniós va instituir com a dinàstic, però que fou atribuït des de bell antuvi, per una falsa tradició, al rei en Jaume (Ivars 1926: 6-22). A la ciutat de Mallorca, en concret, la identificació de la cimera del drac alat amb Jaume I es fa palesa a una escena pictòrica del retaule de sant Jordi, de Pere Niçard i Rafel Mòger (Boncompte 1997; Yarza 1998-1999; Gaita 2010: 38-41), que estigué exposat a ull nu gairebé des del darrer terç del segle XV a la capella de la Confraria de Sant Jordi de l'església de Sant Antoni. L'escena del retaule en qüestió, la batalla a bab al-kofol, es podia observar detalladament, si hom s'acostava, perquè hi estava a la predel la, la part del programa pictòric més pròxima a la visió del fidel. Paga la pena dir, doncs, que una de les parades de la processó de la Festa de l'Estendard es feia a la porta d'aquesta església i que era ací on s'entonaven lletanies a sant Jordi, el sant que s'aparegué a la batalla decisiva durant la Conquesta de Mallorca. L'escena de la batalla a bab al-kofol gaudiria d'un ressò notori per constituir la representació conformadora d'una imatge 
Francesc Granell Sales. La (re)construcció visual i retòrica de Jaume I a la Festa de l'Estendard de Mallorca durant l'època foral

visual de l'esdeveniment, durant el desenvolupament del qual Jaume I, coronat per la cimera del drac alat, atacava les hosts almohades al costat de sant Jordi ${ }^{5}$ [fig. 5].

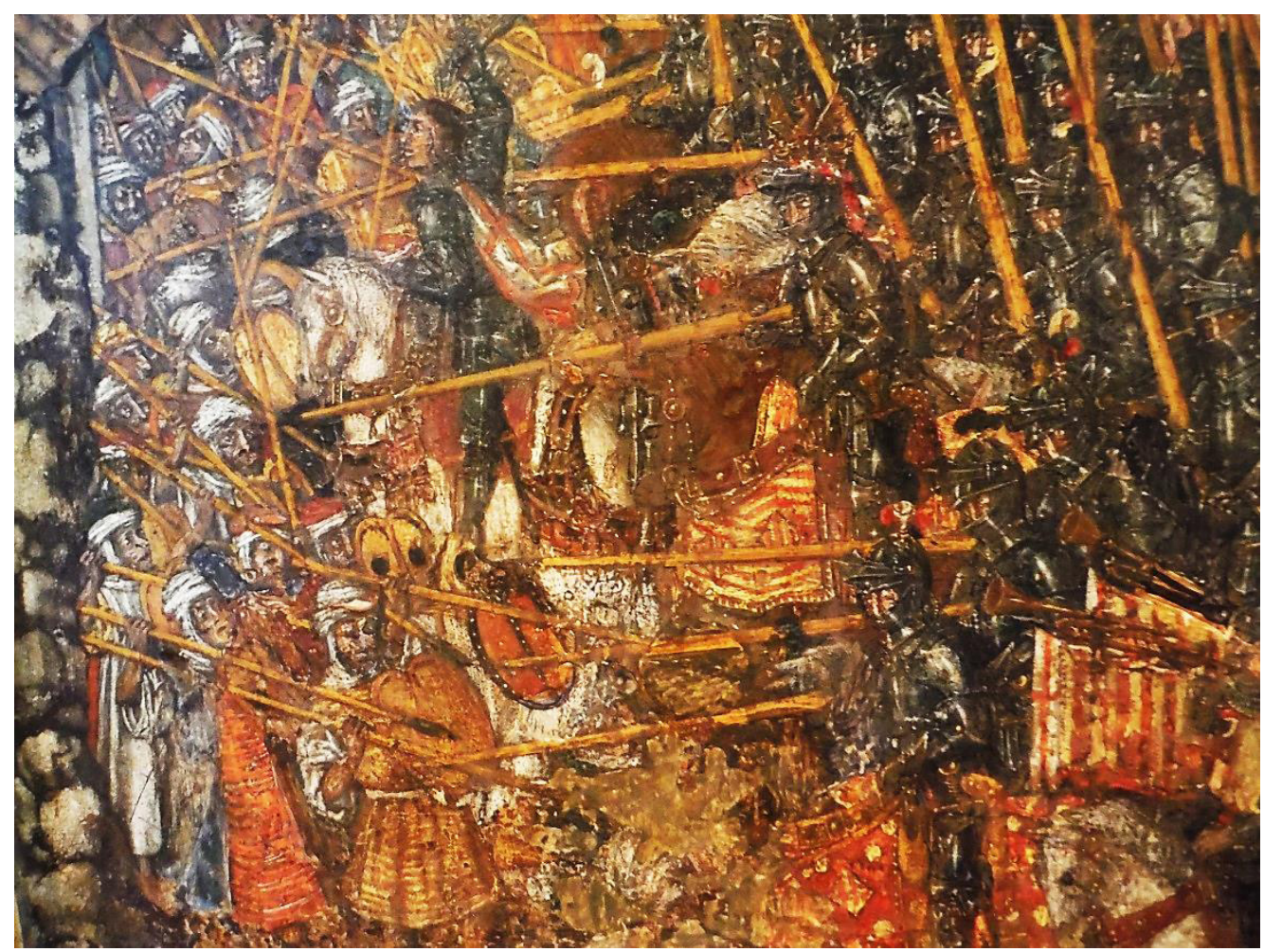

Fig. 5: Detall d'una taula de la predel la del retaule de sant Jordi, Pere Niçard i Rafel

Mòger, 1468-1470, Museu Diocesà de Palma.

A més a més, a aquesta reconstrucció de Jaume I a la festa cívica resten certes reminiscències visuals d'aspectes de les cerimònies funerals baixmedievals de cavallers, nobles, senyors i reis, en les quals un o més hòmens a cavall portaven les armes del difunt en senyal de dol. Aquests rituals, que eren habituals a l'àmbit hispà, a la Corona d'Aragó, tanmateix, van adquirir una dimensió cerimonial desconeguda a Castella (Español 2007: 878). A tall d'exemple, la crònica de les exèquies de Joan II, mort l'any 1479, descriu un personatge singular a la jornada de la solemnitat de la sepultura: «Aprés, un cavaller a cavall, qui aportava una bandera rayal, apellada guió o tallamar, ab salada al cap, en la sima de la qual portava una corona ab lo timbre o ratapinyada reyal» (Cfr. Duran / Sanabre 1930: 312).

5 La tradició oral autòctona jugava un paper essencial pel que fa a la divulgació de relats hagiogràfics durant la tardor de l'Edat Mitjana i, en aquest sentit, la pintura va esdevenir un mitjà de transmissió cabdal (Molina 1997: 5-6). 
Francesc Granell Sales. La (re)construcció visual i retòrica de Jaume I a la Festa de l'Estendard de Mallorca durant l'època foral

\section{Veure i escoltar per recordar}

En suma, els elements ornamentals acoblats a aquell protagonista de la Festa de l'Estendard diluciden una commemoració del rei en Jaume planificada pel poder municipal i aprehesa visualment pel públic assistent a l'esdeveniment. Aquesta visió es va complementar amb la prèdica eloqüent del Sermó de la Conquesta, que enaltia el Conqueridor com un monarca llegendari i miticobíblic, qualitats que va atribuir-se ell mateix al Llibre dels Fets ateses les gestes que havia acomplit.

La reconstrucció a la Festa suposava, doncs, la re-concepció d'un rei que la història no anava a permetre menystenir-lo en oblit. La seua recordació era potent a la ciutat de Mallorca: ell fou qui dotà el regne del primigeni model d'identitat mitjançant l'establiment d'un sistema municipal amb llibertats jurídiques, privilegis i exempcions fiscals (Tudela 2009-2010: 226-227), però, sobretot, fou qui alliberà aquella terra dels sarraïns infidels i qui la constituí com un regne privatiu abans que Pere el Cerimoniós la conquerira a Jaume III. El rei en Jaume va restaurar el cristianisme i plantà la llavor de la pàtria i és per això que la seua veneració a la Festa és incessant: la invocació miticobíblica al Sermó, la veneració del seu retrat a la plaça de Cort per part de les elits executives, les quals gaudien d'una potestat gràcies als privilegis que Jaume I atorgà a la universitas, i la representació a la desfilada que evocava el rei sagrat com a Crist entrant a Terra Santa.

Aquests eren els paràmetres d'una festa multimèdia que apel lava a una societat urbana «sotmesa als impulsos emotius i imaginaris dels retaules, les festes i la literatura de creació» (Serra 2002: 35). Així doncs, les arts i les lletres estaven al servei de l'estat, tot controlant la memòria règia. La Festa de l'Estendard era motiu de consens ciutadà, un acte de sobirania exercit per les institucions municipals respecte a la societat urbana que refermava la cohesió interna (Narbona 2003: 6970), tot enarborant Jaume I, un vincle d'unió entre els cristians mallorquins. Ningú recordava les atrocitats que van cometre les hosts invasores quan entraren en la medina el 31 de desembre de l'any 1229, com sí que va fer l'afamat alfaquí Ibn 'Amira al-Mahzumi en la seua Kitab Ta'Rih Mayurqa (Roser / Rosselló 2008: 60). 
Francesc Granell Sales. La (re)construcció visual i retòrica de Jaume I a la Festa de l'Estendard de Mallorca durant l'època foral

\section{Fonts i bibliografia}

Alomar, A. I. (1994) Les armes mitiques de Jaume I procedents de Mallorca, Palma, Documenta Balear.

—_. (1998) L'Estendard, la festa nacional més antiga d'Europa (s. XIII-XXI), Palma, Documenta Balear.

Biosca, A. (2011) «Las anotaciones del 'Sermó de la Conquesta' en el ms. 40 del Arxiu del Regne de Mallorca», Miscelánea medieval murciana, 35, pp. 51-65.

Boncompte, C. (1997) «El Sant Jordi de Pere Nisart. Enigma en clau de misteri eyckià», Lambard. Estudis d'art medieval, 10, pp. 206-212.

Calafat, R. M. / Quintana, A. (1992) La pervivència del rei en Jaume, Palma, Documenta Balear.

Cingolani, S. M. (2008 [1a ed. 2007]) La memòria dels reis. Les quatre grans cròniques. Barcelona, Base.

—_. (2010) «Jaume I fou un rei piadós?», Catalonia, 5, pp. 1-13.

Dameto, J. (1633) La Historia general del Reyno Baleárico, Ciutat de Mallorca, Gabriel Guasp.

Duran, A. / Sanabre, J. (ed) (1930) Llibre de les solemnitats de Barcelona, Barcelona, Institució Patxot.

Escartí, V. J. (2012) «Jaume I, el 'Llibre dels feits' i l'humanisme: un model 'valencià' per al cesarisme hispànic», eHumanista/IVITRA, 1, pp. 128-140.

Escartí, V. J. / Ferrando, A. (2008) «Estudi introductori», dins Escartí, V. J. / Ferrando, A. (eds.) El Llibre dels Fets, València, Institució Alfons el Magnànim, pp. 9-42.

Español, F. (2007) «El 'córrer les armes'. Un aparte caballeresco en las exequias medievales hispanas», Anuario de Estudios Medievales, 37, vol. 1, pp. 867-905.

Falomir, M. (1996) «Sobre los orígenes del retrato y la aparición del Pintor de Corte en la España bajomedieval», Boletín de Arte (Universidad de Málaga), 17, pp. 177-196.

Font i Obrador, B. (1964) «Mallorca en 1349», Bolletí de la Societat Arqueologica Lul liana, 32, pp. 245260.

Gaita, M. M. (2010) La col Hecció de pintura del Museu Diocesà de Mallorca, Palma, Consell de Mallorca/ Departament de Cultura i patrimoni.

Ivars, A. (1926) Orige i significació del «drach alat» $i$ del «rat penat» en les insignies de la ciutat de València, València, Imprenta hijo de F. Vives Mora.

Llompart, G. (1974) «Cortejos luctuosos y patrióticos», Bolletí de la Societat Arqueològica Lul tiana, 23, pp. 323-329.

—. (1977) «Aspectos medievales de la 'Festa de l'Estandart'», dins Etnología y Tradiciones Populares (Palma de Mallorca, 16-19 de gener de 1975), Saragossa, Institución Fernando el Católico, pp. 207222.

(1980) «La Festa de l'Estandart d'Aragó, una litúrgia municipal europea en Mallorca», Cuadernos de Historia Jerónimo Zurita, 37-38, pp. 7-34. 
Francesc Granell Sales. La (re)construcció visual i retòrica de Jaume I a la Festa de l'Estendard de Mallorca durant l'època foral

Massip, J. F. (2010) La monarquia en escena: teatro, fiesta y espectáculo del poder en los reinos ibéricos, Madrid, Dirección General de Promoción Cultural.

Molina i Figueras, J. (1997) «La ilustración de leyendas autóctonas: el santo y el territorio», Analecta sacra tarraconensia: Revista de ciències historicoeclesiàstiques, 70, pp. 5-24.

Narbona, R. (2003) Memorias de la ciudad: ceremonias, creencias y costumbres en la historia de Valencia, València, Ajuntament de València/Acció Cultural/Delegació de Cultura.

Quintana, A. (1998) La Festa de l'Estendard. Cultura i cerimonial a Mallorca (segles XIV-XX), Catarroja/ Barcelona, Afers.

Roser, N. / Rosselló, G. (trads.) (2008) Kitab Ta’Rih Mayurqa: crònica àrab de la Conquesta de Mallorca, Palma, Presidència de les Illes Balears/Universitat de les Illes Balears.

Serra Desfilis, A. (2002) «Ab recont de grans gestes. Sobre les imatges de la història i de la llegenda en la pintura gòtica de la Corona d'Aragó», Afers, 41, vol. 17, pp. 15-35.

— - (2007) «En torno a Jaime I: de la imagen al mito en el arte de la Corona de Aragón de la Baja Edad Media», dins Mínguez, V (ed.) Visiones de la monarquía hispánica, Castelló, Universitat Jaume I, pp. 321-348.

Serrano, M. (2008) Jaime I el Conquistador: imágenes medievales de un reinado, Saragossa, Institución Fernando el Católico.

Serrano, M. (2011a) «Programas ideológicos a través de la Imagen: algunos ejemplos de la Edad Media», Medievalista online, 9, pp. 2-36.

_- (2011b) «Falsas historias, proposiciones certeras. Dominio visual e imágenes persuasivas en el entorno áulico de la Corona de Aragón», Codex Aequilarensis, 27, pp. 191-212.

—..(2015) 'Effigies regis aragonum'. La imagen figurativa del rey de Aragón en la Edad Media, Saragossa, Institución Fernando el Católico.

Pernoud, R. (1977) Les Hommes de la croisade, París, Tallandier.

Pons i Fàbregues, B. (1907) La bandera de la Ciudad de Mallorca, Ciutat de Mallorca, Imp. Soler.

Sobré, J. M. (1978) L'èpica de la realitat. L'escriptura de Ramon Muntaner i Bernat Desclot, Barcelona, Curial.

Tudela, L. (2009-2010) «El modelo de identidad del reino de Mallorca en la Baja Edad Media», 16, pp. 223-243.

Weyler, F. (1968) Historia militar de Mallorca. XIII-XVIII, Ciutat de Mallorca, De Ayer.

Yarza, J. (1998-1999) «Pere Nisart, un pintor del sud de França a Mallorca», dins Mallorca gòtica (catàleg de l'exposició), MNAC/Govern Balear, Barcelona, pp. 45-50. 